One old friend, himself a distinguished man, who knew James Middlemass from his boyhood, writes : "There is not a single recollection of him I wish to blot out. He was one of the best men I ever knew. . . . He was absolutely unassuming, true to the heart's core, strong with the strength that goes hand in hand with gentleness and courtesy and love. A genuine son of consolation, he laid his great gifts of intellect and skill at the door of those who needed them sorely."

Another, now a University professor, writes: "He certainly possessed all-round powers, and I feel he would have taken an eminent place in almost any branch of the profession. I may add that he was of a gentle and kindly nature, unselfish and absolutely upright in his dealings with his fellows, and always ready to help anyone. I cannot recall anything spoken or done by him with a taint of the unworthy."

"A peace-maker, and one who never undertook to do a thing without doing it," writes one friend; while another says, "His ability had nothing theatrical about it."

James Middlemass certainly never sought the limelight. Perhaps, indeed, he was too reticent, quiet and unassuming to win all the distinctions to which his achievements entitled him. But his influence was profound, and it is a cause for thankfulness that he turned his attention to psychological medicine, since he was uniquely fitted to help people in mental distress.

Though he rarely discussed religion, he was a man of deep religious convictions, and all who knew him will realise the aptness of words quoted by the Chairman of his Committee, Mr. Councillor Taylor, who wrote, "What nobler epitaph can any man have than this, "After he had served his own generation faithfully, by the will of God, he fell on sleep.'"

It seems fitting to conclude this brief record of our friend by a sonnet written by his sister:

REMEMBRANCE.

Fames Middlemass, M.D.

Thanks for the rain upon the thirsty ground,

Thanks too for tears that ease the burdened heart;

But thanks supreme for memories that dart

Their shaft-like glory through the grief around.

Computing these, what are the riches found?

Fair chronicles of one who played his part,

As friend and true physician, with an art

In wise and patient, gentle ways that bound

To him the hearts of many in strong faith

And love and leal devotion. Can such power,

Of origin divine, be held of death

And wither in the dust like any flower?

Nay, 'tis alive-immortal aftermath-

To bless us when we reach death's golden hour.

May, 1922.

Bedford Pierce.

\title{
MarRiott Logan Rowan, M.D., R.U.I.
}

We regret to announce the death, on August 6th, at St. Anne's-on-Sea, of Dr. Rowan, who since 1915 has filled the post of Medical Superintendent of the Derby County Mental Hospital. He was a native of Carrickfergus, co. Antrim, being born there in 1871 , and received his medical education at Queen's College, Belfast. He was a graduate of the Royal University of Ireland, taking his medical degrees M.B., B.Ch., B.A.O., in 1900 after a distinguished arts career. He received the degree of M.D. in 1903 and took up psychiatry in 1904, when he was appointed an assistant medical officer at the same hospital of which he subsequently became the medical chief. His health had been failing for some time but his end came quite suddenly, much to the distress of his many friends and relatives. His loss was keenly felt at his hospital, where he had endeared himself to both staff and patients. He leaves a widow and two young children, to whom we extend our sincere condolence. 